\title{
ON THE NEUTRALITY OF MONEY IN CEE (EU MEMBER) STATES: A PANEL COINTEGRATION ANALYSIS*
}

\author{
Marinko ŠKARE - Manuel BENAZIĆ - Daniel TOMIĆ \\ (Received: 26 January 2016; revision received: 10 June 2016; \\ accepted:25 July 2016)
}

\begin{abstract}
The concept of money neutrality is an important pillar of the mainstream economic literature. It implies that autonomous changes in the money supply have no influence on real macroeconomic variables in the long run. The goal of this paper is to test the validity of (long-run) money neutrality proposition in the CEE (EU member) states. The empirical research is based on panel cointegration analysis which utilises annual data on real output and broad (M2) as well as narrow (M1) monetary aggregates over the 1995-2013 period for 11 ex-socialist EU countries. The results suggest that the money neutrality proposition could be rejected in both cases when narrow or broad measure of money supply is applied, meaning that an active monetary policy could and should be used as a stabilisation instrument as well as in stimulating real economic activity.
\end{abstract}

Keywords: money non-neutrality, monetary policy, panel cointegration analysis, CEE countries

JEL classification indices: C23, E40, E51, E60, F40

* This work was supported by the Croatian Science Foundation, project number 9481, "Modelling Economic Growth - Advanced Sequencing and Forecasting Algorithm". Any opinions, findings, and conclusions or recommendations expressed in this material are those of the author(s) and do not necessarily reflect the views of the Croatian Science Foundation.

Marinko Škare, corresponding author. Professor at the Juraj Dobrila University of Pula, Faculty of Economics and Tourism "Dr. Mijo Mirković”, Croatia. E-mail: mskare@unipu.hr

Manuel Benazić, Associate Professor at the Juraj Dobrila University of Pula, Faculty of Economics and Tourism “Dr. Mijo Mirković”. E-mail: mbenaz@unipu.hr

Daniel Tomić, Assistant Professor at the Juraj Dobrila University of Pula, Faculty of Economics and Tourism “Dr. Mijo Mirković”. Croatia. E-mail: dtomic@unipu.hr 


\section{INTRODUCTION}

The beacon of mainstream macroeconomic theory is the separation of real and nominal variables within the classical dichotomy, which states that even a systematic monetary policy cannot influence real economic activity. Hence, long-run money neutrality is a crucial element of classical models. The vertical aggregate supply curve facilitated the proposition that money is a "veil" affecting only price levels and not real output and employment. The concept of money neutrality is closely related to Fisher's (1977) real rate of interest, Friedman's money illusion (1968), Phelps' (1968) natural rate of unemployment model, and Lucas's (1972) monetary misperception theories. In fact, we can trace contemplations about how monetary change affects relative prices and redistribute resources toward final equilibrium even in Hume's works. Interestingly, we can find a distinct contrast between classical and neoclassical orthodoxy, but also within the neoclassical approach (for example the real business cycle theory). The essence of the classical argument was that money and, in effect, monetary policy played no role in exerting any significant effect on macroeconomic situation, while the neoclassical theory, and especially the monetarists, maintained that money mattered greatly (Osuji - Chigbu 2013). Intriguingly, the theory of real business cycles holds that the economy obeys the classical dichotomy where nominal variables are assumed not to influence real variables. Keynes's (1936) well-known statement that once we recognise money as a real phenomenon, money matters, and the axiom of neutrality must be rejected, reflected the possibility or reality that money affects real variables both in the short and long run. It made room for a post-Keynesian strand and the monetary circuit theory, which emphasised the role of bank lending and credits in the creation of imbalanced economic systems.

In his "The Non-Neutrality of Money", Minsky (1993), labelled as a heterodox economist, also argued that money and money contracts are necessary to economic activity, and therefore money is not just an arbitrary numéraire. Notwithstanding the impact of classical orthodoxy (that reconciled Keynesian short-term influences and classical long-run implications) on economic literature, it seems nowadays that most economists agree that monetary policy has some impact on real variables, as the actual mechanism of such a link is open to considerable debates. In recent years, a number of coherent explanations have been put forward on the topic of the (non)neutrality of money, yet a consensus is still out of sight.

The theoretical part of the debate is an ongoing, probably never-ending process, but the empirical evidence on the neutrality of money has been quite mixed. Following major advances in macro-econometrics, questionable issues in model specification brought the notion of nonstationary time series to the fore of econometric modelling. In fact, as shown by Fisher - Seater (1993), meaningful neutral- 
ity tests can only be developed if money and real variables are nonstationary, and thus subject to permanent shocks (Westerlund - Constantini 2009). As reflected in the issue of nonstationarity, new methodologies for testing long-run neutrality propositions, such as data integration, cointegration properties, and econometric identification problems, were developed (Chuku 2011).

This paper focuses on two conceptual challenges: (a) to include post-socialist countries, often neglected in literature, and (b) to apply recent developments in methodology by using panel cointegration tests that account for the variations in the cross-section and are expected to produce more accurate results when facing short time series. Accordingly, the main objective of the study is to test the validity of long-run money neutrality proposition in 11 Central and Eastern European (EU member) countries through panel cointegration analysis, by using data on real output and two monetary aggregates (M1 and M2) for the period from 1995 until 2013.

The rest of the paper is organised as follows. In Section 2, we will provide a brief overview of the theory on money neutrality and some empirical evidence. Section 3 reviews the methodology and data used, while Section 4 evaluates empirical results and offers some policy implications. Section 5 provides concluding remarks.

\section{A BRIEF REVIEW OF THEORY AND EMPIRICAL EVIDENCE}

\section{The concept of money neutrality}

Economic theory, at least the mainstream one, is based on several universal truths that are often considered as dogmatic by its opponents. There are only a few axioms in classical economics that are less controversial than the long-run neutrality of money, which states that permanent changes in money supply have no longrun effects on the real variables. Therefore, an autonomous increase in the stock of money will increase all prices and wages proportionately, but will have no effect on real output, unemployment levels, or real prices, the implication being that the real income or the level of employment are, in the long term, essentially determined by real factors such as technology, population growth, the preferences of economic agents, or some elements of the institutional framework in an economic system (property rights, tax policy, welfare policy, etc.). This reasoning forces us to the conclusion that even though central banks control money supply and can intervene on the markets, they cannot affect the real economy in the long run just by printing more or less money. In the short run, changes in the money supply will usually affect real variables mainly because of price stickiness and 
the imperfect information flow in the markets. According to some neoclassical economists, a perfectly anticipated monetary policy has no effect on real economic activity even in the short run (Ekomie 2013).

As Chucku (2011) points out well, over the years, the theoretical foundations of the quantity theory of money, from which money neutrality is partly derived, have metamorphosed into what may be described as the long-run neutrality triplex. The first proposition postulates that permanent changes in the money supply have no permanent long-run effects on real output. The second is the Fisher relation, which hypothesises that permanent changes in inflation have no effects on the real interest rate, and the third proposition is that of the vertical long-run Philips curve, which postulates that permanent changes in the rate of inflation cannot change the rate of unemployment. These general principles underline all standard macroeconomic thinking, but they can also influence practical measures, especially if we observe the functioning of monetary policy through a highly complex transmission mechanism that works differently in different economic systems. Namely, there being more consciousness regarding the long-run effect, monetary policy can avoid either unnecessary delays in intervention or restrictive measures during different phases of business cycles. We can say that the challenge of testing monetary neutrality propositions is de facto based on answering the question of whether inflation is merely a monetary phenomenon or not.

Another interesting appearance of the money neutrality theory is the superneutrality concept of money, which is a stronger property. Money superneutrality assumes that not only is the real economy unaffected by the level of the money supply, but also that the rate of money supply growth will not have long-term effects on real variables. Thereby, nominal wages and prices will remain proportional to the nominal money supply not only in response to one time permanent changes in the stock of money, but also in response to permanent changes in the growth rate of the nominal money supply. This can be expected in the short run, but both neutrality and superneutrality propositions are mainly concerned with the long run. Interestingly, whereas long-run neutrality is taken almost as an axiom of monetary economics, long-run superneutrality is far more circumspect (Bullard 1999). This is why an empirical test that suggests departures from the superneutrality proposition should not come as a surprise.

Theoretical analyses dealing with the modelling of the economy, including economic growth, generally assume long-run monetary neutrality. Even in the empirical analyses of business cycles, neutrality is often employed as identifying restriction within structural models (Oi et al. 2004). However, by observing the real world, a glance at the history and its manifold periods of extreme inflationary tendencies and aftermaths may be sufficient to realise that maybe money is not neutral and that the abundance of money will not leave the real and fundamental 
economic structures intact in the long run. Indeed, if we follow Mises's (1912) deductions, which are summarised in the claim that "Money is not neutral or it does not exist", we reach his conclusion that in an ever-changing world of action, there is no room for neutral money. Contemporary theoretical research on monetary non-neutrality primarily focuses on nominal frictions or "stickiness". Next, information asymmetries and lags can also cause non-neutrality. In addition, if money is a utility generating good in and of itself instead of being valued for the goods and services one can trade for it, money can impact real economy. The bounded rationality approach suggests that small contractions in the money supply are not taken into account as economic agents in some decision-making, and that they will therefore spend longer searching for a completed contract than without the monetary contraction. Finally, money can also affect real economic variables if there are real costs associated with holding or not holding it. Moreover, all this includes the non-superneutrality of money because when an economy is adjusting to the new rate of monetary growth, a lot can happen to the real variables in the transition period between the short and long run (Bullard 1999). The real question, as stated by Collignon (2007), is how short-term shocks translate into long-term phenomena.

\section{Empirical relevance}

Empirical studies on money (non)neutrality reveal the true nature of the globalised world by providing divergent results and conclusion in regard to different countries and time spans. Interesting papers that comprised most of the relevant literature on this topic are Fisher - Seater (1993), Weber (1994), King - Watson (1997), Bullard (1999), Karanassou - Sala (2010), and recently Vaona (2015). Many empirical studies on money (non)neutrality were subjected to severe criticism, especially regarding the time-series properties of data. In recent times, scholars have developed new methodologies for testing long-run money neutrality propositions that now take cognizance of hitherto questionable issues of model specification, data integration and cointegration properties, and econometric identification problems (Chuku 2011). First, Fisher - Seater (1993), who analysed the annual data for USA and monthly data for Germany as a historical overview, found little support in favour of long-run money neutrality proposition in the USA and rejected the superneutrality hypothesis for Germany. Again for the USA, King - Watson (1997) analysed the post-war period from 1949 until 1990 and found little evidence against both long-run neutrality and superneutrality. Serletis - Krause (1996) and Serletis - Koustas (1998) employed long-term time-series data that included the pre-war period. These studies reveal that long- 
run monetary neutrality generally holds for wide-ranging periods and countries, namely developed ones. In his review of the literature on monetary neutrality, Vaona (1995) considered a variety of studies differing in terms of models, estimation strategies, data frequencies, and countries analysed, focusing mainly on published works that found positive empirical evidence that money non-neutrality exists.

\section{Some literature on developing countries}

Wallace's (1999) paper on Mexico over the period of 1932-1992 presented results in favour of the hypothesis. Bae - Ratti (2000) considered annual data for Argentina and Brazil over the periods of 1884-1996 and 1912-1995. They found that money neutrality is accepted for Brazil and Argentina, but superneutrality is rejected for both. Nogueira (2007) concluded that inexistence of the longterm relationship between nominal interest rates and real output for Brazil over the 1948-2004 period is in line with the theory of long-run monetary neutrality. Again, by using ARDL modelling for 14 emerging and developed countries, Nogueira (2009) found overall support for the traditional economic theory of money neutrality. Chen (2007) analysed the neutrality proposition for South Korea and Taiwan by employing King - Watson's (1997) methodology. He used quarterly data from 1970 to 2004 for South Korea and from 1965 to 2004 for Taiwan, and found strong support for the long-run money neutrality in the case of South Korea and only a little evidence in favour of the neutrality proposition in the case of Taiwan. Sulku (2011) analysed the long-run money neutrality hypothesis in Turkey for the period of 1987-2006 using Fisher - Seater's (1993) methodology and found strong evidence in favour of the proposition regarding M1, M2, and even M3 monetary aggregate. Ganchev et al. (2014) focused their research on revealing the nature of the relationship between nominal GDP growth and total credit in the CEE countries. They concluded that the lack of substantial interdependence between the nominal GDP and CRED dynamics may be viewed as a confirmation of the long-term neutrality of money.

If we turn to methodological varieties, beside Lucas's and Sargent's papers in the 1970s, Fisher - Seater's (1993) ARIMA framework and King - Watson's (1997) VAR methodology are among the distinguished studies concerning the time-series properties of real output and money aggregates (Sulku 2011). These studies point out two distinct properties that must be considered within long-run money neutrality testing, namely the money exogeneity and stationarity conditions of the time series. Fisher - Seater (1993) suggested that criteria for testing long-run monetary neutrality can be established not by using the money stock 
alone, but rather based on the order of integration of both the money stock and the real variable, meaning that comprehensive neutrality tests can only be evaluated if money and real output are nonstationary and thus subject to permanent shocks. King - Watson (1997), who analysed the robustness of neutrality results to alternative identifying assumptions, underlined the necessity of applying preferably as many tests as possible in the hope that this will make results more confident. Furthermore, the possible presence of cointegration is in itself sufficient for rejecting the money neutrality proposition. This is why Westerlund - Constantini (2009) believe that cointegration tests should be considered as an integral part of neutrality tests and not only as a diagnostic preliminary as is usually the case. Considering the need for a selective approach and the problem of cross-sectional dependency when analysing a sample of countries, Bullard (1999) stresses the importance of accurate unit root and cointegration tests, and suggests that a panel approach might be more appropriate in this respect (Westerlund - Constantini 2009). This acknowledgement is in line with our research perspective. Relatively few papers applied panel (especially cointegration-based) analysis when testing the long-run money neutrality. Westerlund - Constantini's (2009) paper on panel cointegration for ten industrialised countries covering the period from 1870 to 1986 suggested that the null hypothesis of no cointegration between money and real output can be rejected and thus that the neutrality of money can also be rejected. Their two conclusions are of great importance for our study, namely, that (1) most series have missing observations, which not only makes the panel unbalanced, but also reduces the effective number of time-series observations, thus making the cross-sectional dimension a very important source of information, and (2) the cointegration test must be evaluated as an integral part of the neutrality tests with serious efforts pointed towards detecting time-series integration properties.

\section{DATA AND METHODOLOGY}

Vaona (2015) surveyed some of the most important papers on money neutrality and suggested that there is a need for more robustness of the results and more transparency with regard to the adopted instruments and identification assumptions. Interestingly, the available literature tends to pay little attention to prospects of panel surveys, even though the issue of money neutrality pervaded the research patterns for a long-time. Considering the plausibility of the results in this area, we opted for the panel cointegration method. Though panel results may be biased by specific country experience, time averages, unbalanced feature, etc., the problem of not sufficiently long time series lead us to the panel cointegration 
aspect of research. Another important feature is that the use of the panel cointegration framework can ensure econometrically robust results. Next, unit root tests are often limited to results from few generally applied tests such as Augmented Dickey-Fuller or Phillip-Perron test. However, a number of more sophisticated procedures of unit root testing are nowadays available for panel cointegration purposes. In addition, the countries included in the analysis are mutually related historically, politically, socially as well as economically, which makes it logical to study them within the same research domain.

Annual panel data on real gross domestic product (GDP) ${ }^{1}$, nominal money (M1) ${ }^{2}$, and quasi money (M2) ${ }^{3}$ covering the period from 1995 to 2013 for 11 countries were collected from the World Bank's database. Countries included in the analysis are Central and Eastern European EU member states (former socialist countries), i.e. Estonia, Latvia, Lithuania, the Czech Republic, the Slovak Republic, ${ }^{4}$ Hungary, Poland, Romania, Bulgaria, Slovenia, and Croatia. ${ }^{5}$ Data are expressed as logarithms. ${ }^{6}$ This study uses the narrow (M1) and the broad (M2) definition of money since some authors such as Weber (1994) indicate that for broader measures, such as M2 and M3, there is strong evidence in favour of the neutrality of money, while for the narrower definition of money (M1), the evidence is much weaker. Oi et al. (2004) report that long-run monetary neutrality can sometimes be rejected when different types of money stocks are adopted. Therefore, to assure the robustness of our study, we have taken two different monetary aggregates.

As the main goal of this paper is to empirically test the validity of (long-run) money neutrality proposition, the following two equations are estimated:

$$
\begin{aligned}
& \text { Real GDP } P_{i t}=\alpha_{0 i}+\beta_{1 i} M 1_{i t}+u_{i t}, \quad i=1,2, \ldots, N ; \quad t=1,2, \ldots, T \\
& \text { Real GDP } P_{i t}=\alpha_{0 i}+\beta_{1 i} M 2_{i t}+u_{i t}, \quad i=1,2, \ldots, N ; \quad t=1,2, \ldots, T
\end{aligned}
$$

1 Data are in constant 2005 US dollars.

2 Data in current local currencies are converted into US dollars using official national exchange rates.

3 Data in current local currencies are converted into US dollars using official national exchange rates.

$4 \quad$ Data on (M1) and (M2) for the Slovak Republic are available until 2009.

5 Some of the countries (i.e. Slovenia in 2007, the Slovak Republic in 2009, Estonia in 2011, and in later stages Latvia and Lithuania, 2014 and 2015, the last two not important for our period of analysis) have adopted the euro as the national currency and became a part of the eurozone. This may affect the homogeneity of the panel; however, as it will be shown later, this was not the case.

6 For the analysis, EViews econometric software is used. 
where Real GDP represents real gross domestic product, $M 1$ nominal money, $M 2$ nominal money and quasi money, $u_{i t}$ is the error term, while $i$ and $t$ denote country and time, respectively.

Graph 1 presents movements in real GDP, nominal money M1 and nominal money and quasi money M2 (henceforth money M1 and money and quasi money M2) over the observed period. All three variables are showing increasing patterns with almost similar movements over the countries and time. Such similarities in the movements between the variables indirectly point us to the question of sample homogeneity.

Since the countries included in the analysis can be grouped among eurozone countries (Estonia, Latvia, Lithuania, Slovak Republic, and Slovenia) and potential members (Czech Republic, Hungary, Poland, Romania, Bulgaria, and Croatia), i.e. the countries with different monetary regimes (considering they are highly euroised ${ }^{7}$ ), our conclusions must be weighed accordingly. Still, our presumption about the homogeneity among countries is based on two facts. First, most of the selected countries within our period of observation (1995-2013) were open and highly indebted economies with free floating exchange rate regimes (except for Bulgaria with its fixed exchange rate regime), which is also true for those five countries that have adopted the euro. Although we can find some differences in their transmission mechanisms, the similarities in their exchange rate regimes bolster our presumption about the sample homogeneity. Moreover, Slovenia, the Slovak Republic, and Estonia have adopted the euro only in later stages of the observed period, and the introduction of the euro in Latvia and Lithuania in 2014/2015 is not even included in our analysis. It means that the focus of the analysis is on the period prior to the monetary union aspiration for those countries. The presumption about homogeneity ${ }^{8}$ among countries suggests that the panel data approach should be an appropriate method for answering our research question. Another interesting issue is the process of synchronisation.

The notion of synchronisation is frequently related to the question of optimum currency areas, as it has come to be recognised as a prerequisite for any higher

7 It is common to use the term "euroisation" as a concept similar to "dollarisation", where euroisation results from individuals/firms voluntarily choosing to use foreign currency (this time the euro) as either a transaction substitute (currency substitution) or a store of value substitute (asset substitution) for the monetary services of domestic country. Not all of the selected countries have adopted the euro yet, not even within our selected period, so we can say that due to their historical nexus and socio-economic bond with other European countries, these countries are highly euroised.

8 This presumption will also be tested within the empirical part of the analysis by the homogeneity tests, which will suggest statistical insignificance of the heterogeneity in the cointegration equation. 


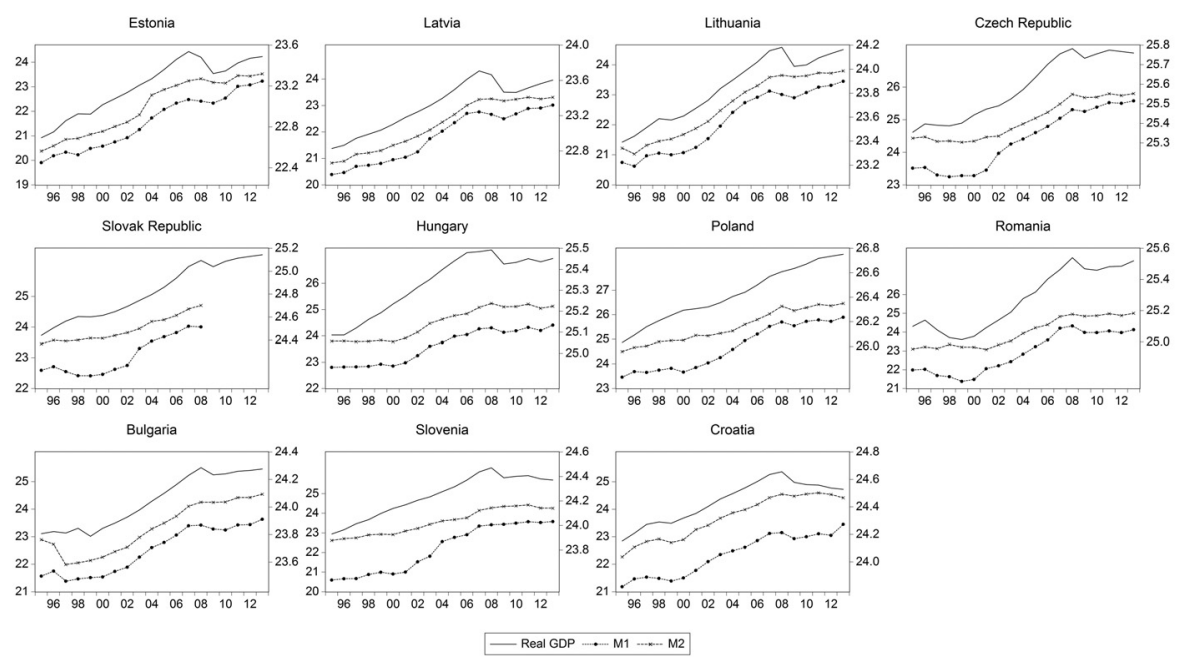

Graph 1. Real GDP, nominal money M1 and nominal money and quasi money M2 (individual cross-sections, in logs)

Source: The World Bank database and authors' calculations.

level of economic integration such as the European Monetary Union. Obviously, the optimality of this delegation of the decisions to a higher authority will be a direct function of the similarities across these economies (Tomić - Kenjereš 2014). If the economies move together, we might think that they need the same type of economic policy decisions at the same time. Thus, the analysis of the main factors/relations such as money neutrality proposition could be of great help in explaining the process and the speed of the adjustments of CEE countries to the European common market and capitalist venues. We can notice that all series achieve strong upward trends with the decline and slowdown during 2007 and 2008 due to the spill-over effect of the crisis on local economies (see Graph 1). Following the international financial crisis, countries have put various stimulus packages into effect to minimise the impacts of the crisis on their own economies and real variables. Hence, countries approached the crisis in a strategic way and took decisions by making analyses not to let the crisis deepen further. An internationally derived set of rules (Maastricht criteria and Fiscal Stability Treaty) additionally complicates the influence of monetary policy in these countries. The fundamental issue surrounding monetary policy and economic activity for the selected countries is related to these two questions; (1) can monetary policy be used to fine-tune the real economic sector, and (2) how to recognise the limitations 
of monetary policies in time perspective. In order to answer these questions by examining the neutrality of money in the selected CEE (EU member) countries, a linear panel data cointegration of time series is applied. The cointegration analysis with panel data is similar to the cointegration usually employed in time-series analysis and consists of unit root tests, cointegration tests, and the estimation of long-run relationship.

\section{Unit root tests}

The analysis starts with conducting a battery of panel unit root tests, as it is very important to determine the order of integration of a time series in order to avoid spurious results, especially since macroeconomic variables are often characterised by non-stationarity. If the series are integrated (non-stationary), the analysis continues with testing for the panel cointegration. Otherwise, a short-run interpretation is appropriate. Therefore, to test the order of integration, the following panel unit root tests are considered: LLC test (Levin et al. 2002), Breitung test (Breitung 2000), IPS test (Im et al. 2003), Fisher-type tests using ADF and PP tests (Maddala - Wu 1999 and Choi 2001), and Hadri test (Hadri 2000). LLC and Breitung tests under the null hypothesis assume a common unit root process, while IPS and Fisher-type tests under the null hypothesis assume individual unit root processes. The Hadri test under the null hypothesis assumes no unit root (stationarity). On the other hand, LLC and Breitung tests under the alternative hypothesis assume no unit root, while IPS and Fisher-type tests assume that some cross-sections are without unit root. Finally, the Hadri test under the alternative hypothesis assumes unit root. For the purpose of the analysis, in the LLC, Breitung, IPS and Fisher-ADF tests, the automatic lag length selection is based on the Schwarz information criterion with a maximum lag of 3. Moreover, to estimate the long-run variance in the LLC and Fisher-PP tests, the Bartlett kernel was used with maximum lags determined by the Newey and West bandwidth selection algorithm.

\section{Panel cointegration tests}

For the purpose of the analysis, we evaluated panel cointegration tests according to Pedroni (1999, 2004), Kao (1999), and Maddala - Wu (1999). Pedroni - Kao extend the two-step Engle-Granger (1987) framework to tests involving panel data. Pedroni proposes several tests for cointegration that allow for heterogeneous intercepts and trend coefficients across cross-sections with two alternative 
hypotheses: the homogenous alternative (the within-dimension test or panel statistics test) and the heterogeneous alternative (the between-dimension or group statistics test). The Kao test follows the same approach as the Pedroni tests, but specifies cross-section specific intercepts and homogeneous coefficients on the first-stage regressors. Maddala - Wu (1999) applied Fisher's combined test (Fisher 1932) that uses the results of the individual independent tests and Johansen's test methodology (Johansen 1991, 1995) to propose an alternative approach to testing for cointegration in panel data by combining tests from individual cross-sections in order to obtain test statistics for the full panel. These tests may provide unreliable results since they require correct specifications and individual testing. Due to research homogeneity, within Pedroni's cointegration test the automatic lag length selection is based on the Schwarz information criterion with lags from 2 to 3, while the spectral estimation used in computing the test statistic or statistics is based on the Newey-West automatic bandwidth selection and Bartlett kernel. The same is done within the Kao cointegration test, except that the automatic lag length selection is set to a maximum of 2. In the Johansen Fisher cointegration test, lags interval in first differences is set to 1 .

\section{Estimation of the long-run model}

The long-run relationship is estimated using the pooled Panel Fully Modified Least Squares (FMOLS), pooled Panel Dynamic Least Squares (DOLS), and pooled Mean Group/AR Distributed Lag (PMG/ARDL) estimation methods. All these methods assume the existence of a single cointegrating vector between panel data, which is empirically relevant, since this analysis in fact explores the relationship between two variables, i.e. real GDP and money M1, and real GDP and money and quasi money M2.

Phillips - Moon (1999), Pedroni (2000), and Kao - Chiang (2000) proposed extensions of the Phillips - Hansen (1990) FMOLS estimator to panel settings, while Kao - Chiang (2000), Mark - Sul (1999, 2003), and Pedroni (2001) propose extensions of the Saikkonen (1992) and Stock - Watson (1993) DOLS estimator. FMOLS and DOLS estimation methods for panel settings allow the estimation of panel cointegrating regression equation for non-stationary data by correcting the standard pooled OLS for serial correlation and endogeneity of regressors that are usually present in long-run relationships. In addition, panel DOLS allows augmenting the panel cointegrating regression equation with cross-section specific lags and leads to eliminate the endogenity and serial correlation. The PMG/ ARDL (Pesaran et al. 1999) takes the cointegration form of the simple ARDL model and adapts it for a panel setting by allowing the intercepts, short-run coef- 
ficients, and cointegrating terms to differ across cross-sections. Therefore, the main advantage over the FMOLS and DOLS is that it can allow the short-run dynamic specification to differ across cross-sections, while the long-run coefficients are constrained to be invariant. For the purpose of the analysis, in the FMOLS and DOLS, the default (homogenous variances) coefficient covariance matrix computations use an estimator of the long-run variance computed using a Bartlett kernel and fixed Newey-West bandwidth. Moreover, in DOLS estimation method, lags and leads are specified using the automatic lag length selection based on the Schwarz information criterion. In the PMG/ARDL, the automatic lag length selection of dependent variable and dynamic regressors is based on the Schwarz criterion with a maximum lag of 2 . Finally, to test the neutrality of money M1 and money and quasi money M2, zero restrictions are imposed on the long-run parameters using the Wald test.

\section{RESULTS AND DISCUSSION}

Generally, unit root tests indicate that the variables are integrated, i.e. they are nonstationary in level and stationary in first differences (see Table 8 in the Appendix). Although we had noticed some diversity within unit root tests, additional graphical analysis supported our hypothesis about non-stationarity. Therefore, a panel cointegration test can be implemented. The following tables present the results of the Pedroni, Kao and Johansen Fisher panel cointegration tests between real GDP and money M1, and between real GDP and money and quasi money M2.

When only intercept is included, most of the Pedroni's statistics reject the null hypothesis of no cointegration between variables, indicating the existence of a long-run panel cointegration relationship between real GDP and M1, and between real GDP and M2.

Hence, it can be concluded that money is not neutral in the long run (Table 1). On the other hand, results and conclusion regarding the neutrality of money in the long run differs when intercept and trend are included since only one statistic rejects the null hypothesis of no cointegration between real GDP and money M1, and between real GDP and money and quasi money M2.

Kao's panel cointegration test strongly rejects the null hypothesis of no cointegration between variables, indicating the existence of a long-run panel cointegration relationship between the observed variables (Table 2). According to these residual cointegration tests, we can deduce that money is not neutral in the long run. Let us evaluate the results of the combined cointegration test.

Johansen Fisher trace and maximum eigenvalue cointegration tests (restricted and unrestricted constant cases) strongly reject the null hypothesis of no cointe- 
Table 1. Pedroni residual cointegration test

\begin{tabular}{|c|c|c|c|c|c|c|c|c|}
\hline \multicolumn{9}{|c|}{ Variables: GDP, M1 } \\
\hline & \multicolumn{4}{|c|}{ Intercept } & \multicolumn{4}{|c|}{ Intercept and trend } \\
\hline & Statistic & Prob. & $\begin{array}{l}\text { Weighted } \\
\text { statistic }\end{array}$ & Prob. & Statistic & Prob. & $\begin{array}{l}\text { Weighted } \\
\text { statistic }\end{array}$ & Prob. \\
\hline $\begin{array}{l}\text { Panel } \\
\text { v-Statistic }\end{array}$ & 1.806911 & 0.0354 & 2.094525 & 0.0181 & 0.125305 & 0.4501 & -0.119090 & 0.5474 \\
\hline $\begin{array}{l}\text { Panel rho- } \\
\text { Statistic }\end{array}$ & -0.499201 & 0.3088 & -1.322427 & 0.0930 & 1.670319 & 0.9526 & 1.103945 & 0.8652 \\
\hline $\begin{array}{l}\text { Panel PP- } \\
\text { Statistic }\end{array}$ & -1.438287 & 0.0752 & -2.519659 & 0.0059 & 0.630080 & 0.7357 & -0.334229 & 0.3691 \\
\hline $\begin{array}{l}\text { Panel ADF- } \\
\text { Statistic }\end{array}$ & -2.855589 & 0.0021 & -3.603794 & 0.0002 & -0.269409 & 0.3938 & -1.043761 & 0.1483 \\
\hline $\begin{array}{l}\text { Group rho- } \\
\text { Statistic }\end{array}$ & 0.061350 & 0.5245 & & & 2.036274 & 0.9791 & & \\
\hline $\begin{array}{l}\text { Group PP- } \\
\text { Statistic }\end{array}$ & -2.134873 & 0.0164 & & & 0.482952 & 0.6854 & & \\
\hline $\begin{array}{l}\text { Group } \\
\text { ADF- } \\
\text { Statistic }\end{array}$ & -4.644277 & 0.0000 & & & -1.967568 & 0.0246 & & \\
\hline \multicolumn{9}{|c|}{ Variables: GDP, M2 } \\
\hline & \multicolumn{4}{|c|}{ Intercept } & \multicolumn{4}{|c|}{ Intercept and trend } \\
\hline & Statistic & Prob. & $\begin{array}{l}\text { Weighted } \\
\text { statistic }\end{array}$ & Prob. & Statistic & Prob. & $\begin{array}{c}\text { Weighted } \\
\text { statistic }\end{array}$ & Prob. \\
\hline $\begin{array}{l}\text { Panel } \\
\text { v-Statistic }\end{array}$ & 1.511717 & 0.0653 & 1.273404 & 0.1014 & -0.721723 & 0.7648 & -0.621726 & 0.7329 \\
\hline $\begin{array}{l}\text { Panel rho- } \\
\text { Statistic }\end{array}$ & -1.184923 & 0.1180 & -0.996104 & 0.1596 & 1.256432 & 0.8955 & 1.523544 & 0.9362 \\
\hline $\begin{array}{l}\text { Panel PP- } \\
\text { Statistic }\end{array}$ & -2.747432 & 0.0030 & -2.559551 & 0.0052 & -0.421207 & 0.3368 & 0.158961 & 0.5632 \\
\hline $\begin{array}{l}\text { Panel ADF- } \\
\text { Statistic }\end{array}$ & -3.783227 & 0.0001 & -3.233616 & 0.0006 & -1.739677 & 0.0410 & -1.013860 & 0.1553 \\
\hline $\begin{array}{l}\text { Group rho- } \\
\text { Statistic }\end{array}$ & 0.346001 & 0.6353 & & & 2.424440 & 0.9923 & & \\
\hline $\begin{array}{l}\text { Group PP- } \\
\text { Statistic }\end{array}$ & -2.605715 & 0.0046 & & & 0.602908 & 0.7267 & & \\
\hline $\begin{array}{l}\text { Group } \\
\text { ADF- } \\
\text { Statistic }\end{array}$ & -3.583799 & 0.0002 & & & -0.801284 & 0.2115 & & \\
\hline
\end{tabular}

Source: Authors' calculations.

Table 2. Kao residual cointegration test (individual intercept)

\begin{tabular}{l|l|l}
\hline \multirow{2}{*}{ Variables } & \multicolumn{2}{|l}{ ADF } \\
\cline { 2 - 3 } & t-Statistic & Prob. \\
\hline GDP, M1 & -4.045168 & 0.0000 \\
\hline GDP, M2 & -4.972011 & 0.0000 \\
\hline
\end{tabular}

Source: Authors' calculations. 
Table 3. Johansen Fisher panel cointegration test (Trace and Maximum Eigenvalue)

\begin{tabular}{l|c|c|c|c|c|c|c|c}
\hline & \multicolumn{7}{c}{ Variables: GDP, M1 } \\
\hline \multirow{2}{*}{$\begin{array}{l}\text { Hypothesised } \\
\text { No. of CE(s) }\end{array}$} & $\begin{array}{c}\text { Nisher } \\
\text { Stat.* }\end{array}$ & Prob. & $\begin{array}{c}\text { Fisher } \\
\text { Stat.** }\end{array}$ & Prob. & $\begin{array}{c}\text { Fisher } \\
\text { Stat.* }\end{array}$ & Prob. & $\begin{array}{c}\text { Fisher } \\
\text { Stat.** }\end{array}$ & Prob. \\
\hline None & 47.81 & 0.0011 & 42.14 & 0.0060 & 52.06 & 0.0003 & 48.51 & 0.0009 \\
\hline At most 1 & 26.99 & 0.2116 & 26.99 & 0.2116 & 31.88 & 0.0795 & 31.88 & 0.0795 \\
\hline \multicolumn{8}{|c|}{ Variables: GDP, M2 } \\
\hline
\end{tabular}

Note: Fisher statistical probabilities are computed using asymptotic Chi-square distribution. * from trace test.

** from max-eigenvalue test.

Source: Authors' calculations.

gration between variables, indicating the existence of a long-run panel cointegration relationship between real GDP and money M1, and between real GDP and money and quasi money M2 (Table 3). According to these results, money is not neutral in the long run either. In addition, Table 9 and Table 10 in the Appendix suggest individual cross-section results. From these results we can see that cointegration is present in more countries when using a broader definition of money (M2), meaning that these findings are in accordace with those obtained by Weber (1994). Cross-section results indicate that when a narrow definition of money (M1) is used, cointegration is present in Hungary, Poland, and Bulgaria. On the other hand, when a broad definition of money (M2) is used, cointegration is present in almost all countries, except Estonia and Croatia. However, the Johansen Fisher panel cointegration results may vary according to the number of lags used in estimation and due to other specifications. Table 4 presents the panel cointegration results from the FMOLS, DOLS and PMG/ARDL estimation methods between real GDP and money M1, testing the long-run linear cointegration relations.

The results indicate that the long-run coefficients obtained from all estimation methods are positive and strongly significant, varying from 0.18 to 0.21 , except for the coefficient obtained from the PMG/ARDL restricted constant case estimation, which is higher. Accordingly, it can be concluded that money M1 as a narrow definition is not neutral in the long run. 
Table 4. Panel cointegration results (Pooled estimation) - GDP; M1

\begin{tabular}{|c|c|c|c|c|c|c|c|c|}
\hline \multicolumn{9}{|c|}{ Panel Fully Modified Least Squares (FMOLS) } \\
\hline \multirow[b]{2}{*}{ Variable } & \multicolumn{4}{|c|}{ Constant } & \multicolumn{4}{|c|}{ Constant and trend } \\
\hline & $\begin{array}{c}\text { Coeffi- } \\
\text { cient }\end{array}$ & $\begin{array}{l}\text { Std. } \\
\text { Error }\end{array}$ & $\begin{array}{c}\text { t-Statis- } \\
\text { tic }\end{array}$ & Prob. & $\begin{array}{c}\text { Coeffi- } \\
\text { cient }\end{array}$ & $\begin{array}{l}\text { Std. } \\
\text { Error }\end{array}$ & $\begin{array}{l}\text { t-Statis- } \\
\text { tic }\end{array}$ & Prob. \\
\hline M1 & 0.205709 & 0.007822 & 26.29936 & 0.0000 & 0.196669 & 0.020685 & 9.508018 & 0.0000 \\
\hline \multicolumn{9}{|c|}{ Panel Dynamic Least Squares (DOLS) } \\
\hline & \multicolumn{4}{|c|}{ Constant } & \multicolumn{4}{|c|}{ Constant and trend } \\
\hline Variable & $\begin{array}{c}\text { Coeffi- } \\
\text { cient }\end{array}$ & $\begin{array}{l}\text { Std. } \\
\text { Error }\end{array}$ & $\begin{array}{l}\mathrm{t}-\text { Statis- } \\
\text { tic }\end{array}$ & Prob. & $\begin{array}{c}\text { Coeffi- } \\
\text { cient }\end{array}$ & $\begin{array}{l}\text { Std. } \\
\text { Error }\end{array}$ & $\begin{array}{l}\text { t-Statis- } \\
\text { tic }\end{array}$ & Prob. \\
\hline M1 & 0.200871 & 0.007712 & 26.04519 & 0.0000 & 0.211672 & 0.022423 & 9.440121 & 0.0000 \\
\hline \multicolumn{9}{|c|}{ PMG/ARDL (Pooled Mean Group/AR Distributed Lag)* } \\
\hline & \multicolumn{4}{|c|}{ Restricted constant } & \multicolumn{4}{|c|}{ Unrestricted constant } \\
\hline Variable & $\begin{array}{c}\text { Coeffi- } \\
\text { cient }\end{array}$ & $\begin{array}{l}\text { Std. } \\
\text { Error }\end{array}$ & $\begin{array}{c}\text { t-Statis- } \\
\text { tic }\end{array}$ & Prob. & $\begin{array}{c}\text { Coeffi- } \\
\text { cient }\end{array}$ & $\begin{array}{l}\text { Std. } \\
\text { Error }\end{array}$ & $\begin{array}{c}\text { t-Statis- } \\
\text { tic } \\
\end{array}$ & Prob. \\
\hline M1 & 0.479944 & 0.086012 & 5.579940 & 0.0000 & 0.180907 & 0.007632 & 23.70455 & 0.0000 \\
\hline
\end{tabular}

Note: * selected model: ARDL $(1,1)$.

Source: Authors' calculations.

Zero restrictions on the long-run parameters are tested using the Wald test. It is clearly visible from Table 5 that the null hypothesis can be strongly rejected, confirming once again that money M1 is not neutral in the long run.

The following table presents the panel cointegration results from FMOLS, DOLS and PMG/ARDL estimation methods between real GDP and money and quasi money M2.

Table 6 indicates that the long-run coefficients obtained from all estimation methods are positive and strongly significant varying from 0.20 to 0.26 , except the coefficient obtained from the PMG/ARDL restricted constant case estimation, which is higher. According to the results, it can be concluded that money and quasi money M2 as a broader definition is also not neutral in the long run. Additionally, the results suggest that when a broader definition of money is used, then the long-run coefficients are a bit higher compared to those when a narrower definition of money is used. Analogously, to test the neutrality of money and quasi money M2, zero restrictions are imposed on the long-run parameters using the Wald test. The results are shown in the following table.

Similar to the case with money M1, the null hypothesis is again strongly rejected, confirming that monetary aggregate M2 is not neutral in the long run ( $\mathrm{Ta}$ ble 7). Finally, in order to check the possible heterogeneity of the pooled FMOLS and DOLS estimates, the group-mean FMOLS and DOLS results of the same specifications are obtained and compared to those from the pooled estimation. The results are very similar, suggesting that heterogeneity in the cointegrating 
Table 5. Long-run Wald test coefficient restrictions $(\mathrm{M} 1=0)$

\begin{tabular}{|c|c|c|c|c|c|c|}
\hline \multicolumn{7}{|c|}{ Panel Fully Modified Least Squares (FMOLS) } \\
\hline \multirow[b]{2}{*}{ Test Statistic } & \multicolumn{3}{|c|}{ Constant } & \multicolumn{3}{|c|}{ Constant and trend } \\
\hline & Value & df & Prob. & Value & df & Prob. \\
\hline t-statistic & 26.29936 & 181 & 0.0000 & 9.508018 & 170 & 0.0000 \\
\hline F-statistic & 691.6562 & $(1,181)$ & 0.0000 & 90.40240 & $(1,170)$ & 0.0000 \\
\hline Chi-square & 691.6562 & 1 & 0.0000 & 90.40240 & 1 & 0.0000 \\
\hline \multicolumn{7}{|c|}{ Panel Dynamic Least Squares (DOLS) } \\
\hline & \multicolumn{3}{|c|}{ Constant } & \multicolumn{3}{|c|}{ Constant and trend } \\
\hline Test Statistic & Value & $\mathrm{df}$ & Prob. & Value & df & Prob. \\
\hline t-statistic & 26.04519 & 158 & 0.0000 & 9.440121 & 147 & 0.0000 \\
\hline F-statistic & 678.3521 & $(1,158)$ & 0.0000 & 89.11589 & $(1,147)$ & 0.0000 \\
\hline Chi-square & 678.3521 & 1 & 0.0000 & 89.11589 & 1 & 0.0000 \\
\hline \multicolumn{7}{|c|}{ PMG/ARDL (Pooled Mean Group/AR Distributed Lag) } \\
\hline & \multicolumn{3}{|c|}{ Restricted constant } & \multicolumn{3}{|c|}{ Unrestricted constant } \\
\hline Test Statistic & Value & $\mathrm{df}$ & Prob. & Value & df & Prob. \\
\hline t-statistic & 5.579940 & 170 & 0.0000 & 23.70455 & 159 & 0.0000 \\
\hline F-statistic & 31.13574 & $(1,170)$ & 0.0000 & 561.9059 & $(1,159)$ & 0.0000 \\
\hline Chi-square & 31.13574 & 1 & 0.0000 & 561.9059 & 1 & 0.0000 \\
\hline
\end{tabular}

Source: Authors' calculations.

Table 6. Panel cointegration results (Pooled estimation) - GDP; M2

\begin{tabular}{|c|c|c|c|c|c|c|c|c|}
\hline \multicolumn{9}{|c|}{ Panel Fully Modified Least Squares (FMOLS) } \\
\hline \multirow[b]{2}{*}{ Variable } & \multicolumn{4}{|c|}{ Constant } & \multicolumn{4}{|c|}{ Constant and trend } \\
\hline & $\begin{array}{c}\text { Coeffi- } \\
\text { cient }\end{array}$ & $\begin{array}{c}\text { Std. } \\
\text { Error }\end{array}$ & $\begin{array}{c}\text { t-Statis- } \\
\text { tic }\end{array}$ & Prob. & $\begin{array}{c}\text { Coeffi- } \\
\text { cient }\end{array}$ & $\begin{array}{c}\text { Std. } \\
\text { Error }\end{array}$ & \begin{tabular}{|c|} 
t-Statis- \\
tic \\
\end{tabular} & Prob. \\
\hline M2 & 0.244028 & 0.007491 & 32.57754 & 0.0000 & 0.251451 & 0.019710 & 12.75756 & 0.0000 \\
\hline \multicolumn{9}{|c|}{ Panel Dynamic Least Squares (DOLS) } \\
\hline & \multicolumn{4}{|c|}{ Constant } & \multicolumn{4}{|c|}{ Constant and trend } \\
\hline Variable & $\begin{array}{c}\text { Coeffi- } \\
\text { cient }\end{array}$ & $\begin{array}{c}\text { Std. } \\
\text { Error }\end{array}$ & \begin{tabular}{|c|} 
t-Statis- \\
tic
\end{tabular} & Prob. & $\begin{array}{c}\text { Coeffi- } \\
\text { cient }\end{array}$ & $\begin{array}{c}\text { Std. } \\
\text { Error }\end{array}$ & \begin{tabular}{|c|}
$\begin{array}{c}\text { t-Statis- } \\
\text { tic }\end{array}$ \\
\end{tabular} & Prob. \\
\hline M2 & 0.241827 & 0.006667 & 36.27308 & 0.0000 & 0.255438 & 0.018041 & 14.15909 & 0.0000 \\
\hline \multicolumn{9}{|c|}{ PMG/ARDL (Pooled Mean Group/AR Distributed Lag)* } \\
\hline & \multicolumn{4}{|c|}{ Restricted constant } & \multicolumn{4}{|c|}{ Unrestricted constant } \\
\hline Variable & $\begin{array}{c}\text { Coeffi- } \\
\text { cient }\end{array}$ & $\begin{array}{l}\text { Std. } \\
\text { Error }\end{array}$ & $\begin{array}{c}\text { t-Statis- } \\
\text { tic } \\
\end{array}$ & Prob. & $\begin{array}{c}\text { Coeffi- } \\
\text { cient }\end{array}$ & $\begin{array}{l}\text { Std. } \\
\text { Error }\end{array}$ & \begin{tabular}{|c} 
t-Statis- \\
tic
\end{tabular} & Prob. \\
\hline M2 & 0.525122 & 0.030789 & 17.05572 & 0.0000 & 0.197360 & 0.026940 & 7.325931 & 0.0000 \\
\hline
\end{tabular}

Note: * selected model: ARDL $(1,1)$.

Source: Authors' calculations. 
Table 7. Long-run Wald test coefficient restrictions $(\mathrm{M} 2=0)$

\begin{tabular}{|c|c|c|c|c|c|c|}
\hline \multicolumn{7}{|c|}{ Panel Fully Modified Least Squares (FMOLS) } \\
\hline \multirow[b]{2}{*}{ Test Statistic } & \multicolumn{3}{|c|}{ Constant } & \multicolumn{3}{|c|}{ Constant and trend } \\
\hline & Value & df & Prob. & Value & $\mathrm{df}$ & Prob. \\
\hline t-statistic & 32.57754 & 181 & 0.0000 & 12.75756 & 170 & 0.0000 \\
\hline F-statistic & 1061.296 & $(1,181)$ & 0.0000 & 162.7554 & $(1,170)$ & 0.0000 \\
\hline Chi-square & 1061.296 & 1 & 0.0000 & 162.7554 & 1 & 0.0000 \\
\hline \multicolumn{7}{|c|}{ Panel Dynamic Least Squares (DOLS) } \\
\hline & \multicolumn{3}{|c|}{ Constant } & \multicolumn{3}{|c|}{ Constant and trend } \\
\hline Test Statistic & Value & df & Prob. & Value & df & Prob. \\
\hline t-statistic & 36.27308 & 148 & 0.0000 & 14.15909 & 137 & 0.0000 \\
\hline F-statistic & 1315.737 & $(1,148)$ & 0.0000 & 200.4797 & $(1,137)$ & 0.0000 \\
\hline Chi-square & 1315.737 & 1 & 0.0000 & 200.4797 & 1 & 0.0000 \\
\hline \multicolumn{7}{|c|}{ PMG/ARDL (Pooled Mean Group/AR Distributed Lag) } \\
\hline & \multicolumn{3}{|c|}{ Restricted constant } & \multicolumn{3}{|c|}{ Unrestricted constant } \\
\hline Test Statistic & Value & df & Prob. & Value & df & Prob. \\
\hline t-statistic & 17.05572 & 170 & 0.0000 & 7.325931 & 159 & 0.0000 \\
\hline F-statistic & 290.8975 & $(1,170)$ & 0.0000 & 53.66927 & $(1,159)$ & 0.0000 \\
\hline Chi-square & 290.8975 & 1 & 0.0000 & 53.66927 & 1 & 0.0000 \\
\hline
\end{tabular}

Source: Authors' calculations.

equation or the long-run covariances is not important (not displayed here, but can be obtained upon request).

The results of this study have interesting implications. The main conclusion is that permanent changes in the stock of money do have long-run real effects. Our results suggest monetary policy can be effective in stimulating real economic activities. Though most of the countries we observed had a relatively stable inflation, our results favour the conclusion that monetary policy can be useful in sustaining inflation by checking the money supply. Moreover, both money and money and quasi money measures seem to have a relatively persistent influence on real outputs, suggesting in some ways that monetary policy might even be useful for nominal GDP targeting, confirming its importance as a constructive economic tool not only in the short run, but also as a long-run measure. Next, the long-run relationship between real GDP and different monetary aggregates was fairly narrow, meaning that changes in money supply will result in limited real output reach. It means that contrary to standard economic thinking and money neutrality propositions, money probably matters in the long run, but not extremely. Monetary policy should therefore be considered as an extremely efficient tool for short-term stabilisation, an important factor in reducing inflation/deflation 
tendencies within the middle-term perspective and a measure with a limited longrun development dimension.

Another interesting fact is that our study includes countries that now have different monetary regimes: one group that belongs to the eurozone and one group with a highly euroised monetary system. This could also play an important role within a possible policy implementation reach, especially for those countries that still have an autonomous monetary policy. Thus, it can be the cause of possible nonlinearities in the long-run effect of money on real output. Most of these countries have leftovers from ex systems in respect to the different strength of unions, which also diminishes the possible real effects of a money supply change. Also, imperfect price adjustments, general price-relative price confusion, and low business confidence that may characterise the economic decisions of the new common market members could be the sources of money non-neutrality. Hence, it would be interesting to reveal the origin of the possible source of these nonneutralities.

In the end, we have to say that the major contribution of this paper is the finding that real economic developments in the CEE (EU member) countries are in direct causal relationship not only to real (non-monetary) factors such as technological improvements, but also to money, because money supply changes obviously generated new demand patterns in these countries, ditto money must have had a longrun effect. As stated by Vaona (2015), by knowing this monetary policy-making might turn less conflictual, gaining credibility, and it might also help in avoiding either unnecessary delays in interventions or too restrictive stances.

\section{CONCLUSION}

Theoretical discussions and a plethora of empirical works that go hand in hand with the non-neutrality of money - a property that monetary policy indeed affects real outcomes - have shaken the pedestal of mainstream economic thinking. It seems that the question "Does money matter?" has never left us for real. The aim of this study was to test the validity of the long-term neutrality of money hypothesis for selected EU countries in order to provide a better understanding of monetary policy possibilities. By using the panel cointegration method, we provided empirical evidence from 11 post-socialist countries, which showed that autonomous changes in money supply influenced the level of real output in the long run, regardless of the measure of monetary aggregate we choose to include in the analysis. It means that the change in the stock of money cannot be considered purely as a monetary phenomenon, and thus the observed countries have the contingency to govern real economic activity through monetary policy. 
The main contribution of the paper is that we shed some light on the monetary policy dilemmas that post-socialist countries in the EU are facing by applying a panel-based approach, which enabled us to make robust conclusions regarding the money neutrality proposition. These conclusions can be tempered by two important caveats. The first is a relatively short time series, which cast some doubts on the accuracy of unit root and cointegration tests. But we have to point out that if the observed period is relatively short, as explained in Fisher - Seater (1993), if there were sudden changes in money and prices, then the data set is qualified to be used for controlling a long-run relation. The second is that our panel cointegration results might be biased by a country specific chain of events, time averages, missing observation, and strength of unit root test. Both can impose scantiness in economic reasoning; however, we find these arguments as an incentive for further research that might include longer annual data or other frequency data, tests that will consider the possible presence of the fractional integration in time series, the development of a model that would contain both the money supply and government expenditure, and a research framework which would include the more advanced EU countries in one panel cointegration analysis.

\section{REFERENCES}

Bae, S. K. - Ratti, R. A. (2000): Long Run Neutrality, High Inflation and Bank Insolvencies in Argentina and Brazil. Journal of Monetary Economics, 46(3): 581-604.

Breitung, J. (2000): The Local Power of Some Unit Root Tests for Panel Data. In: Baltagi, D. (ed.): Nonstationary Panels, Panel Cointegration, and Dynamic Panels, Advances in Econometrics. Elsevier Science Inc., pp. 161-178.

Bullard, J. B. (1999): Testing Long-Run Monetary Neutrality Propositions: Lessons from the Recent Research. Federal Reserve Bank of St. Luis Review, 81(6): 57-77.

Chen, S. W. (2007): Evidence of the Long-Run Neutrality of Money: The Case of South Korea and Taiwan. Economics Bulletin, 3(64): 1-18.

Choi, I. (2001): Unit Root Tests for Panel Data. Journal of International Money and Finance, 20(2): 249-272.

Chuku, A. C. (2011): Testing Long-Run Neutrality Propositions in a Developing Economy: The Case of Nigeria. Journal of Economic Research, 16: 291-308.

Collignon, S. (2007): Long Run Effects of Short-Term Non-Neutrality of Money. Discussion Paper series (in preparation), Institut für Makroökonomie und Konjunkturforschung (IMK) in der Hans Böckler Stiftung, Berlin/Düsseldorf.

ECB (2011): The Monetary Policy of the ECB. Frankfurt, Germany.

Ekomie, J-J. T. (2013): A Multivariate Long-Run Money Neutrality Investigation: Empirical Evidence for CAMEU. Modern Economy, 4(5): 384-390.

Engle, R. F. - Granger, C. W. J. (1987): Co-Integration and Error Correction: Representation, Estimation, and Testing. Econometrica, 55(2): 251-276.

Fisher, I. (1977): The Theory of Interest (1930). Porcupine Press: Philadelphia. 
Fisher, M. E. - Seater, J. J. (1993): Long-Run Neutrality and Superneutrality in an ARIMA Framework. American Economic Review, 83(3): 402-415.

Fisher, R. A. (1932): Statistical Methods for Research Workers. $4^{\text {th }}$ Edition. Edinburgh: Oliver \& Boyd

Friedman, M. (1698): The Role of Monetary Policy. American Economic Review, 68(1): 1-17.

Ganchev, G. - Tsenkov, V. - Stavrova, E. (2014): Exploring the Relationship between Credit and Nominal GDP. The European Money and Finance Forum. Available at: http://www.suerf.org/ download/studies/study20144.pdf.

Hadri, K. (2000): Testing for Stationarity in Heterogeneous Panel Data. Econometrics Journal, 3(2): 148-161.

IHS Global Inc. (2015): EViews 9 User's Guide. Irvine CA: USA.

Im, K. S. - Pesaran, M. H. - Shin, Y. (2003): Testing for Unit Roots in Heterogeneous Panels. Journal of Econometrics, 115(1): 53-74.

Johansen, S. (1991): Estimation and Hypothesis Testing of Cointegration Vectors in Gaussian Vector Autoregressive Models. Econometrica, 59(6): 1551-1580.

Johansen, S. (1995): Likelihood-Based Inference in Cointegrated Vector Autoregressive Models. Oxford: Oxford University Press.

Kao, C. (1999): Spurious Regression and Residual-Based Tests for Cointegration in Panel Data. Journal of Econometrics, 90(1): 1-44.

Kao, C. - Chiang, M. H. (2000): On the Estimation and Inference of a Cointegrated Regression in Panel Data. In: Baltagi, B. (ed.): Advances in Econometrics, 15: Nonstationary Panels, Panel Cointegration, and Dynamic Panels, Elsevier Science Inc., pp. 179-222.

Karanassou, M. - Sala, H. (2010): The US Inflation - Unemployment Tradeoff Revisited: New Evidence for Policy Making. Journal of Policy Modelling, 32(6): 758-777.

Keynes, J. M. (1936): The General Theory of Employment, Interest and Money. New York: Harcourt Brace.

King, R. G. - Watson, M. W. (1997): Testing Long-Run Neutrality. Federal Reserve Bank of Richmond Economic Quarterly, 83(3): 69-101.

Levin, A. - Lin, C. - Chu, C. (2002): Unit Root Tests in Panel Data: Asymptotic and Finite-Sample Properties. Journal of Econometrics, 108(1): 1-24.

Lucas, R. E. Jr. (1972): Expectations and the Neutrality of Money. Journal of Economic Theory, 4(2): 103-124.

Maddala, G. S. - Wu, S. (1999): A Comparative Study of Unit Root Tests with Panel Data and a New Simple Test. Oxford Bulletin of Economics and Statistics, 61(S1): 631-652.

Minsky, H. (1993): On the Non-Neutrality of Money. Federal Reserve Bank of New York Quarterly Review, 18(1): 77-82.

Mises, L. von (1912): The Theory of Money and Credit, (1971) Irvington-on-Hudson: New York, Foundation for Economic Education.

Nelson, M. C. - Sul, D. (1999): A Computationally Simple Cointegration Vector Estimator for Panel Data. Ohio State University manuscript.

Nelson, M. C. - Sul, D. (2003): Cointegration Vector Estimation by Panel DOLS and Long-Run Money Demand. Oxford Bulletin of Economics and Statistics, 65(5): 655-680.

Nogueira Jr., R. P. (2007): Some Evidence on Long-Run Monetary Policy Neutrality in Brazil. Revista de Economia e Administração, 6(4): 438-446.

Nogueira Jr., R. P. (2009): Is Monetary Policy Really Neutral in the Long-Run? Evidence for Some Emerging and Developed Economies. Economics Bulletin, 29(3): 2432-2437. 
Oi, H. - Shiratsuka, S. - Shirota, T. (2004): On Long-Run Monetary Neutrality in Japan. Monetary and Economic Studies, October 2004, Bank of Japan's Institute for Monetary and Economic Studies.

Osuji, C. C. - Chigbu, E. E. (2013): Money Neutrality Controversy in a Developing Economy. Developing Country Studies, 3(1): 170-175.

Pedroni, P. (1999): Critical Values for Cointegration Tests in Heterogeneous Panels with Multiple Regressors. Oxford Bulletin of Economics and Statistics, 61, Special Issue, pp. 653-670.

Pedroni, P. (2000): Fully Modified OLS for Heterogeneous Cointegrated Panels In: B. Baltagi (ed.): Advances in Econometrics, 15: Nonstationary Panels, Panel Cointegration, and Dynamic Panels, Elsevier Science Inc., pp. 93-130.

Pedroni, P. (2001): Purchasing Power Parity Tests in Cointegrated Panels. The Review of Economics and Statistics, 83(4): 727-731.

Pedroni, P. (2004): Panel Cointegration; Asymptotic and Finite Sample Properties of Pooled Time Series Tests with an Application to the PPP Hypothesis. Econometric Theory, 20(3): 597-625.

Pesaran, M. H. - Shin, Y. - Smith, R. P. (1999): Pooled Mean Group Estimation of Dynamic Heterogeneous Panels. Journal of the American Statistical Association, 94(446): 621-634.

Phelps, E. S. (1968): Money - Wage Dynamics and Labour - Market Equilibrium. Journal of Political Economy, 76(4): 678-711.

Phillips, P. C. B. - Hansen, B. E. (1990): Statistical Inference in Instrumental Variables Regression with I(1) Processes. Review of Economics Studies, 57(1): 99-125.

Phillips, P. C. B. - Moon, H. R. (1999): Linear Regression Limit Theory for Nonstationary Panel Data. Econometrica, 67(5): 1057-1111.

Saikkonen, P. (1992): Estimation and Testing of Cointegrated Systems by an Autoregressive Approximation. Econometric Theory, 8(1): 1-27.

Sargent, T. - Wallace, N. (1973): The Stability of Models of Money and Growth with Perfect Foresight. Econometrica, 41(6): 1043-1048.

Serletis, A. - Koustas, Z. (1998): International Evidence on the Neutrality of Money. Journal of Money, Credit and Banking, 30(1): 1-25.

Serletis, A. - Krause, D. (1996): Empirical Evidence on the Long-Run Neutrality Hypothesis Using Low Frequency International Data. Economic Letters, 50(3): 323-327.

Stock, J. H. - Watson, M. (1993): A Simple Estimator of Cointegrating Vectors in Higher Order Integrated Systems. Econometrica, 61(4): 783-820.

Sulku, S. N. (2011): Testing the Long Run Neutrality of Money in a Developing Country: Evidence from Turkey. Journal of Applied Economics and Business Research, 1(2): 65-74.

Tomić, D. - Kenjereš, M. (2015): New Insights in Business Cycle Coherence; Empirical Evidence from Slovenia. $34^{\text {th }}$ International Conference on Organizational Science Development: Internationalization and Cooperation, pp. 1150-1161. Portorož, Slovenia, March 25-27.

Vaona, A. (2015): Anomalous Empirical Evidence on Money Long-Run Superneutrality and the Vertical Long-Run Phillips Curve. Working paper No. 17, Working Paper Series from Department of Economics, University of Verona.

Wallace, F. H. (1999): Long Run Neutrality of Money in the Mexican Economy. Applied Economics Letters, 6(10): 637-639.

Weber, A. (1994): Testing Long-Run Neutrality: Empirical Evidence for G7 Countries with Special Emphasis on Germany. Carnegie-Rochester Conference Series on Public Policy, pp. 67-117.

Westerlund, J. - Constantini, M. (2009): Panel Cointegration and the Neutrality of Money. Empirical Economics, 36(1): 1-26. 


\section{APPENDIX}

Table 8. Panel unit root tests

\begin{tabular}{|c|c|c|c|c|}
\hline \multirow[b]{2}{*}{ Variable and test } & \multicolumn{2}{|c|}{ Level } & \multicolumn{2}{|c|}{ First difference } \\
\hline & Intercept & $\begin{array}{l}\text { Intercept } \\
\text { and trend }\end{array}$ & Intercept & $\begin{array}{l}\text { Intercept } \\
\text { and trend }\end{array}$ \\
\hline Levin, Lin and Chu t* & \multicolumn{4}{|c|}{ Prob.** } \\
\hline GDP & 0.0005 & 0.7309 & 0.0000 & 0.0000 \\
\hline M1 & 0.6080 & 0.0396 & 0.0000 & 0.0000 \\
\hline M2 & 0.0291 & 0.6635 & 0.0000 & 0.0000 \\
\hline Breitung t-stat & \multicolumn{4}{|c|}{ Prob.** } \\
\hline GDP & - & 0.9534 & - & 0.0000 \\
\hline M1 & - & 0.0585 & - & 0.0007 \\
\hline M2 & - & 0.5801 & - & 0.0000 \\
\hline Im, Pesaran and Shin W-stat & \multicolumn{4}{|c|}{ Prob.** } \\
\hline GDP & 0.7203 & 0.8253 & 0.0000 & 0.0016 \\
\hline M1 & 0.9999 & 0.0093 & 0.0000 & 0.0292 \\
\hline M2 & 0.9954 & 0.5496 & 0.0000 & 0.0000 \\
\hline ADF - Fisher Chi-square & \multicolumn{4}{|c|}{ Prob.*** } \\
\hline GDP & 0.8502 & 0.5667 & 0.0003 & 0.0085 \\
\hline M1 & 1.0000 & 0.0236 & 0.0003 & 0.0912 \\
\hline M2 & 0.9744 & 0.3022 & 0.0000 & 0.0005 \\
\hline ADF - Choi Z-stat & \multicolumn{4}{|c|}{ Prob.*** } \\
\hline GDP & 0.7533 & 0.9102 & 0.0000 & 0.0007 \\
\hline M1 & 1.0000 & 0.0161 & 0.0000 & 0.0156 \\
\hline M2 & 0.9944 & 0.7049 & 0.0000 & 0.0001 \\
\hline PP - Fisher Chi-square & \multicolumn{4}{|c|}{ Prob.*** } \\
\hline GDP & 0.7763 & 1.0000 & 0.0015 & 0.0395 \\
\hline M1 & 1.0000 & 0.9949 & 0.0001 & 0.0829 \\
\hline M2 & 0.9983 & 0.9958 & 0.0000 & 0.0001 \\
\hline $\mathrm{PP}-$ Choi Z-stat & \multicolumn{4}{|c|}{ Prob.*** } \\
\hline GDP & 0.6432 & 1.0000 & 0.0001 & 0.0055 \\
\hline M1 & 1.0000 & 0.9493 & 0.0000 & 0.0120 \\
\hline M2 & 0.9997 & 0.9993 & 0.0000 & 0.0000 \\
\hline Hadri Z-stat & \multicolumn{4}{|c|}{ Prob.** } \\
\hline GDP & 0.0000 & 0.0000 & 0.0607 & 0.0006 \\
\hline M1 & 0.0000 & 0.0012 & 0.6544 & 0.0000 \\
\hline M2 & 0.0000 & 0.0000 & 0.1171 & 0.0000 \\
\hline
\end{tabular}


Table 8. cont.

\begin{tabular}{l|c|c|c|c}
\hline \multirow{2}{*}{ Variable and test } & \multicolumn{2}{|c|}{ Level } & \multicolumn{2}{c}{ First difference } \\
\cline { 2 - 5 } & Intercept & $\begin{array}{c}\text { Intercept } \\
\text { and trend }\end{array}$ & Intercept & $\begin{array}{c}\text { Intercept } \\
\text { and trend }\end{array}$ \\
\hline Hadri-HC* Z-stat & \multicolumn{4}{|c}{ Prob.** } \\
\hline GDP & 0.0000 & 0.0000 & 0.0339 & 0.0001 \\
\hline M1 & 0.0000 & 0.0014 & 0.7058 & 0.0000 \\
\hline M2 & 0.0000 & 0.0000 & 0.0834 & 0.0000 \\
\hline
\end{tabular}

Notes: * heteroscedastic consistent, ** probabilities are computed assuming asymptotic normality, *** probabilities are computed using an asymptotic Chi-square distribution.

Source: Author's calculations.

Table 9. Johansen Fisher panel cointegration test - Individual cross section results - GDP; M1

\begin{tabular}{|c|c|c|c|c|c|c|c|c|}
\hline \multirow[b]{2}{*}{ 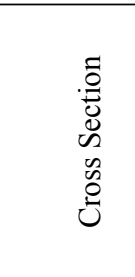 } & \multicolumn{4}{|c|}{$\begin{array}{l}\text { No deterministic trend } \\
\text { (restricted constant) }\end{array}$} & \multicolumn{4}{|c|}{ Linear deterministic trend } \\
\hline & 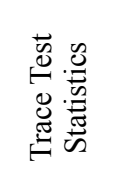 & $\begin{array}{l}\text { *. } \\
\stackrel{0}{0} \\
0\end{array}$ & 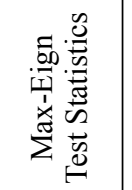 & $\begin{array}{l}\text { * } \\
\stackrel{0}{0} \\
0\end{array}$ & 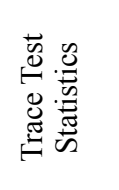 & $\begin{array}{l}\text { *. } \\
\text { Oे } \\
0\end{array}$ & 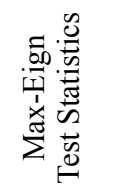 & $\begin{array}{l}* \\
\stackrel{0}{0} \\
0\end{array}$ \\
\hline \multicolumn{9}{|c|}{ Hypothesis of no cointegration } \\
\hline Estonia & 17.9886 & 0.0998 & 13.6628 & 0.1085 & 12.0247 & 0.1557 & 11.6248 & 0.1255 \\
\hline Latvia & 17.7650 & 0.1065 & 12.1913 & 0.1751 & 12.8873 & 0.1190 & 10.2269 & 0.1975 \\
\hline Lithuania & 17.3708 & 0.1193 & 10.4214 & 0.2975 & 11.8453 & 0.1645 & 9.8037 & 0.2251 \\
\hline $\begin{array}{l}\text { Czech } \\
\text { Republic }\end{array}$ & 15.2858 & 0.2104 & 12.6620 & 0.1507 & 13.1797 & 0.1084 & 12.3263 & 0.0990 \\
\hline $\begin{array}{l}\text { Slovak } \\
\text { Republic }\end{array}$ & 14.7418 & 0.2415 & 10.1804 & 0.3182 & 11.9139 & 0.1611 & 10.1745 & 0.2007 \\
\hline Hungary & 21.9976 & 0.0286 & 13.9315 & 0.0991 & 18.6019 & 0.0164 & 13.4381 & 0.0672 \\
\hline Poland & 19.6881 & 0.0598 & 15.1315 & 0.0655 & 14.8334 & 0.0627 & 14.4783 & 0.0463 \\
\hline Romania & 12.6087 & 0.3959 & 11.0209 & 0.2503 & 11.0852 & 0.2063 & 11.0191 & 0.1533 \\
\hline Bulgaria & 22.8825 & 0.0213 & 19.9236 & 0.0110 & 19.4892 & 0.0118 & 19.2812 & 0.0074 \\
\hline Slovenia & 15.7719 & 0.1853 & 9.0512 & 0.4284 & 12.9385 & 0.1171 & 8.8090 & 0.3024 \\
\hline Croatia & 14.7391 & 0.2417 & 9.9291 & 0.3409 & 9.5604 & 0.3161 & 9.4835 & 0.2481 \\
\hline \multicolumn{9}{|c|}{ Hypothesis of at most 1 cointegration relationship } \\
\hline Estonia & 4.3258 & 0.3658 & 4.3258 & 0.3658 & 0.3998 & 0.5272 & 0.3998 & 0.5272 \\
\hline Latvia & 5.5737 & 0.2263 & 5.5737 & 0.2263 & 2.6605 & 0.1029 & 2.6605 & 0.1029 \\
\hline Lithuania & 6.9493 & 0.1291 & 6.9493 & 0.1291 & 2.0416 & 0.1530 & 2.0416 & 0.1530 \\
\hline $\begin{array}{l}\text { Czech } \\
\text { Republic }\end{array}$ & 2.6238 & 0.6530 & 2.6238 & 0.6530 & 0.8534 & 0.3556 & 0.8534 & 0.3556 \\
\hline
\end{tabular}


Table 9. cont.

\begin{tabular}{|c|c|c|c|c|c|c|c|c|}
\hline \multirow[b]{2}{*}{ 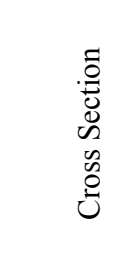 } & \multicolumn{4}{|c|}{$\begin{array}{l}\text { No deterministic trend } \\
\text { (restricted constant) }\end{array}$} & \multicolumn{4}{|c|}{ Linear deterministic trend } \\
\hline & 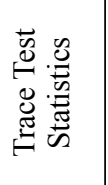 & $\begin{array}{l}\text { *. } \\
\text { oे } \\
0\end{array}$ & 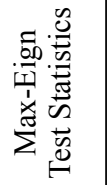 & $\begin{array}{l}\text { *. } \\
\text { :ं } \\
0\end{array}$ & 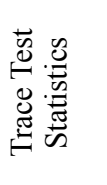 & $\begin{array}{l}\text { *. } \\
\text { :ं } \\
\text { D. }\end{array}$ & 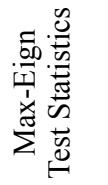 & $\begin{array}{l}\text { *. } \\
\text { مे } \\
\dot{0}\end{array}$ \\
\hline $\begin{array}{l}\text { Slovak } \\
\text { Republic } \\
\end{array}$ & 4.5614 & 0.3349 & 4.5614 & 0.3349 & 1.7393 & 0.1872 & 1.7393 & 0.1872 \\
\hline Hungary & 8.0662 & 0.0805 & 8.0662 & 0.0805 & 5.1639 & 0.0231 & 5.1639 & 0.0231 \\
\hline Poland & 4.5566 & 0.3355 & 4.5566 & 0.3355 & 0.3551 & 0.5512 & 0.3551 & 0.5512 \\
\hline Romania & 1.5878 & 0.8574 & 1.5878 & 0.8574 & 0.0661 & 0.7971 & 0.0661 & 0.7971 \\
\hline Bulgaria & 2.9588 & 0.5884 & 2.9588 & 0.5884 & 0.2079 & 0.6484 & 0.2079 & 0.6484 \\
\hline Slovenia & 6.7207 & 0.1419 & 6.7207 & 0.1419 & 4.1295 & 0.0421 & 4.1295 & 0.0421 \\
\hline Croatia & 4.8099 & 0.3049 & 4.8099 & 0.3049 & 0.0769 & 0.7815 & 0.0769 & 0.7815 \\
\hline
\end{tabular}

Notes: Lags interval (in first differences): 1. * MacKinnon-Haug-Michelis (1999) p-values.

Source: Author's calculations.

Table 10. Johansen Fisher panel cointegration test - Individual cross-section results - GDP; M2

\begin{tabular}{|c|c|c|c|c|c|c|c|c|}
\hline \multirow{2}{*}{ 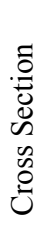 } & \multicolumn{4}{|c|}{$\begin{array}{l}\text { No deterministic trend } \\
\text { (restricted constant) }\end{array}$} & \multicolumn{4}{|c|}{ Linear deterministic trend } \\
\hline & 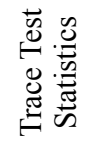 & $\begin{array}{l}\text { *. } \\
\text { : } \\
0\end{array}$ & 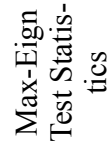 & $\begin{array}{l}* \\
\text { * } \\
\text { D }\end{array}$ & 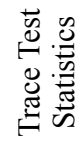 & $\begin{array}{l}* \\
\text { *0 } \\
0 \\
0\end{array}$ & 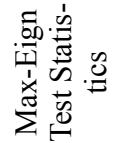 & $\begin{array}{l}* \\
\text { * } \\
0 \\
0\end{array}$ \\
\hline
\end{tabular}

Hypothesis of no cointegration

\begin{tabular}{l|r|r|r|r|r|r|r|r}
\hline Estonia & 15.3043 & 0.2094 & 10.6764 & 0.2767 & 12.2382 & 0.1459 & 10.6478 & 0.1728 \\
\hline Latvia & 27.6876 & 0.0039 & 22.5235 & 0.0039 & 24.7531 & 0.0015 & 21.5811 & 0.0029 \\
\hline Lithuania & 29.6726 & 0.0019 & 17.5418 & 0.0273 & 21.3493 & 0.0058 & 16.8826 & 0.0188 \\
\hline $\begin{array}{l}\text { Czech } \\
\text { Republic }\end{array}$ & 27.8923 & 0.0036 & 24.1518 & 0.0020 & 25.8900 & 0.0010 & 23.6281 & 0.0013 \\
\hline $\begin{array}{l}\text { Slovak } \\
\text { Republic }\end{array}$ & 23.2239 & 0.0190 & 16.8565 & 0.0352 & 21.3843 & 0.0058 & 16.7699 & 0.0197 \\
\hline Hungary & 22.7065 & 0.0226 & 11.9455 & 0.1892 & 19.3045 & 0.0127 & 11.9011 & 0.1144 \\
\hline Poland & 18.0282 & 0.0986 & 15.7344 & 0.0529 & 14.5648 & 0.0687 & 13.9606 & 0.0558 \\
\hline Romania & 18.2517 & 0.0923 & 16.4354 & 0.0411 & 15.9223 & 0.0431 & 15.7635 & 0.0288 \\
\hline Bulgaria & 38.0004 & 0.0001 & 33.2340 & 0.0000 & 33.9933 & 0.0000 & 33.0912 & 0.0000 \\
\hline Slovenia & 19.0508 & 0.0727 & 11.6184 & 0.2092 & 16.8036 & 0.0316 & 10.4221 & 0.1857 \\
\hline Croatia & 11.8504 & 0.4623 & 8.2813 & 0.5145 & 9.2565 & 0.3422 & 6.1535 & 0.5936 \\
\hline
\end{tabular}


Table 10. cont.

\begin{tabular}{|c|c|c|c|c|c|c|c|c|}
\hline \multirow{2}{*}{ 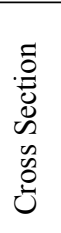 } & \multicolumn{4}{|c|}{$\begin{array}{l}\text { No deterministic trend } \\
\text { (restricted constant) }\end{array}$} & \multicolumn{4}{|c|}{ Linear deterministic trend } \\
\hline & 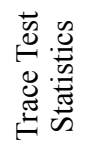 & $\begin{array}{l}* \\
\text { D. } \\
0 \\
0\end{array}$ & 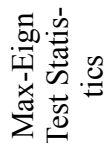 & $\begin{array}{l}* \\
\text { *. } \\
0 \\
0\end{array}$ & 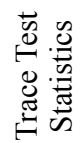 & $\begin{array}{l}\text { *. } \\
\text { : } \\
0 \\
0\end{array}$ & 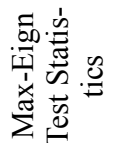 & * \\
\hline
\end{tabular}

Hypothesis of at most 1 cointegration relationship

\begin{tabular}{l|r|r|r|r|r|r|r|r}
\hline Estonia & 4.6279 & 0.3267 & 4.6279 & 0.3267 & 1.5904 & 0.2073 & 1.5904 & 0.2073 \\
\hline Latvia & 5.1641 & 0.2659 & 5.1641 & 0.2659 & 3.1720 & 0.0749 & 3.1720 & 0.0749 \\
\hline Lithuania & 12.1308 & 0.0133 & 12.1308 & 0.0133 & 4.4667 & 0.0346 & 4.4667 & 0.0346 \\
\hline $\begin{array}{l}\text { Czech } \\
\text { Republic }\end{array}$ & 3.7405 & 0.4521 & 3.7405 & 0.4521 & 2.2619 & 0.1326 & 2.2619 & 0.1326 \\
\hline $\begin{array}{l}\text { Slovak } \\
\text { Republic }\end{array}$ & 6.3674 & 0.1642 & 6.3674 & 0.1642 & 4.6144 & 0.0317 & 4.6144 & 0.0317 \\
\hline Hungary & 10.7610 & 0.0247 & 10.7610 & 0.0247 & 7.4034 & 0.0065 & 7.4034 & 0.0065 \\
\hline Poland & 2.2938 & 0.7188 & 2.2938 & 0.7188 & 0.6042 & 0.4370 & 0.6042 & 0.4370 \\
\hline Romania & 1.8163 & 0.8139 & 1.8163 & 0.8139 & 0.1588 & 0.6903 & 0.1588 & 0.6903 \\
\hline Bulgaria & 4.7664 & 0.3100 & 4.7664 & 0.3100 & 0.9021 & 0.3422 & 0.9021 & 0.3422 \\
\hline Slovenia & 7.4324 & 0.1054 & 7.4324 & 0.1054 & 6.3815 & 0.0115 & 6.3815 & 0.0115 \\
\hline Croatia & 3.5690 & 0.4801 & 3.5690 & 0.4801 & 3.1030 & 0.0781 & 3.1030 & 0.0781 \\
\hline
\end{tabular}

Notes: Lags interval (in first differences): 1. * MacKinnon-Haug-Michelis (1999) p-values.

Source: Author's calculations. 